\title{
低レイノルズ数 2 方程式乱流モデルの汎用性について On General Applicability of Low-Reynolds Number Two-Equation Turbulence Models
}

\author{
横嶋 哲**中山 昭彦** \\ Satoshi YOKOJIMA and Akihiko NAKAYAMA
}

\author{
*学生会員 \\ 神戸大学大学院自然科学研究科（广657-8501 神戸市灘区六甲台町1-1） \\ **正会員 Ph.D. 神戸大学教授 大学院自然科学研究科（干657-8501 神戸市灘区六甲台町1-1）
}

\begin{abstract}
General applicability of recently-developed low-Reynolds number two-equation turbulence models using isotropic eddy viscosity, are examined by conducting calculations of flows past a backward-facing step and over a rectangular cavity in the bottom bed of open channels, by comparing with recent direct simulation results. These flows contain features of many general complex flows, such as separation and stagnation and are suited for the present purpose. Models that appropriately incorporate the low-Reynolds number effects near solid walls are found to perform fairly well in the test flows and it is expected that these simple models can further be improved to be a practical method of prediction with wide enough applicability if the effects of the Reynolds stress anisotropy can be taken into account.
\end{abstract}

Keywords: turbulence model, separation, reattachment, , $k$ - $\omega$ model, backward-facing step, cavity flow

\section{1.はじめに}

実用的乱流の予測計算法には，広い適用範囲，高い 予測精度に加えて，計算効率の良さが要求される．近 年汎用性と精度で優れているラージエディーシミュ レーション（LES）法がいろいろな流れに応用されつ つあるが，計算量が多く実用計算に用いるには計算機 の更なる性能向上が必要である. それに対してレイノ ルズ平均運動方程式と乱流モデルを用いる方法は, 汎 用性と精度が向上すれば実用計算には非常に有用であ る. 乱流モデルでは渦粘性仮定を用いる 2 方程式モデ ルが, 汎用性で劣っているものの, その簡便さ, 効率 の良さから実用計算には最もよく用いられている. 3 次元流の計算では 2 次流発生源の応力が表現できない などの根本的問題があるが，2次元流計算ではまだ有 用である. 特に, 近年発表されている低レイノルズ数 モデルは壁まで積分でき, 初期のモデル（例えば Launder \& Spalding ${ }^{1)}$ ) が壁面近傍で局所平衡の成り
立つ流れに限られる壁関数を用いているのに対し，剥 離や再付着を伴う流れにも適用できるとされ，その汎 用性が期待されている. 低レイノルズ数モデルは数多 く発表されている2)が, 幾つかのモデルは近年得られ ている直接シミュレーション（DNS）結果との詳細な 検証により，モデル定数，モデル関数が調節されてお り以前のモデルに比べ予測性能が格段に向上してい る.しかし，これらのモデルの汎用性はあまり検討さ れていない. すなわち, 検証例は平行平板間内で十分 発達した流れなど単純な境界のものが殆どである. 著 者ら $3-4)$ は剥離, 再付着を伴う段落ち流れについて近 年提唱されている低レイノルズ数型 2 方程式モデルの 有用性を検討している. しかし, 汎用性の検討は更に 異なった特性のある非平衡な流れにおいてもなされる ベきである.

水路凹部流れは剥離, 再付着現象に加え, 段上がり 部でせん断流が衝突し, 全体の流れに大きな影響を及 ぼす新たな要素を含んでいる58)。凹部深さに対する 
長さの比（アスペクト比）により, 複雑な干渉乱流と

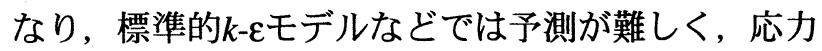
モデルが必要になると指摘されている8). 原因は垂直 応力と異方性が重要になることや境界近傍の低レイノ ルズ数領域の扱い方の問題などが考えられる. 前者は 等方渦粘性の問題であるが後者は境界条件と低レイノ ルズ数領域の扱いの問題である. 何れにしても乱流モ デルの汎用性の検証に適したベンチマーク的流れであ る.

本研究では壁近傍の低レイノルズ数領域をきちんと 扱うモデルが剥離, 再付着する流れのみならず, 剥離 せん断層と下流壁とが干渉するような複雑な流れ場を ぞの程度予測できるかを調べ，モデルの有用性，汎用 性を客観的に検証する．検証には近年得られている DNS結果を用いている．検証したモデルは 2 方程式モ デルの代表である $k-\varepsilon$ 系低レイノルズ数モデルと, 汎 用性で優れているとされている $k$ - $\omega$ 系低レイノルズ数 モデルの最新モデルである.

\section{2. 低レイノルズ数 2 方程式モデルの概要}

2 次元開水路流で $x_{1}$ を路床に平行な流れ方向の座 標, $x_{2}$ を鉛直上向きの座標, $\left(U_{1}, U_{2}\right)$ を $\left(x_{1}, x_{2}\right)$ 方向の 平均流速成分, $P$ を平均圧力とすると, 密度 $\rho$, 動粘 性係数 $\vee$ 水の基礎運動方程式は

$$
\begin{gathered}
\frac{\partial U_{i}}{\partial t}+U_{j} \frac{\partial U_{i}}{\partial x_{j}}=-\frac{1}{\rho} \frac{\partial P}{\partial x_{i}}+g_{i}+\frac{\partial}{\partial x_{j}}\left(\vee \frac{\partial U_{i}}{\partial x_{j}}-\overline{u_{i} u_{j}}\right) \\
\frac{\partial U_{i}}{\partial x_{i}}=0
\end{gathered}
$$

である。ここで, $g_{i}$ は重力の加速度の $x_{i}$ 方向成 分, $-\overline{u_{i} u_{j}}$ はレイノルズ応力である. 境界条件はモ デルによるが, 低レイノルズ数乱流モデルでは, 上式 を壁面まで適用し，壁面では粘着条件が用いられる. 水面では圧力及びせん断応力がゼロである.

本研究で検証するモデルは全てレイノルズ応力を等 方渦粘性を用いて表わす 2 方程式モデルで, 近年発表

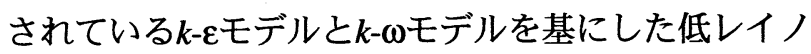
ルズ数モデルから評価の高いものを選んだ. それらは Kawamura \& Kawashima ${ }^{9}$ によるものとNagano \&

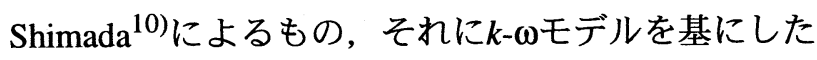

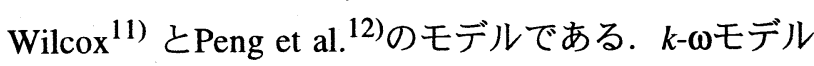
は $k$ と単位エネルギー当たりの散逸率 $\omega$ を渦粘性係数を

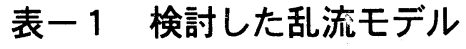

\begin{tabular}{|c|c|c|c|}
\hline & & 提唱者 & 略記 \\
\hline \multirow{4}{*}{$k-\varepsilon$} & 標淮型 & Launder \& Spalding & SKE \\
\cline { 2 - 4 } & \multirow{2}{*}{ 低 $R e$ 数型 } & $\begin{array}{c}\text { Kawamura \& } \\
\text { Kawashima }\end{array}$ & LEK \\
\cline { 3 - 4 } & & Nagano \& Shimada $^{(0)}$ & LEN \\
\hline \multirow{2}{*}{$k-\omega$} & \multirow{2}{*}{ 低 $R e$ 数型 } & Wilcox $^{11)}$ & LOW \\
\cline { 3 - 4 } & & Peng et $_{\text { al. }}{ }^{12)}$ & LOP \\
\hline
\end{tabular}

\section{表ー2 LEKモデルの詳細}

$$
\begin{aligned}
& v_{t}=C_{\mu} f_{\mu} \frac{k^{2}}{\widetilde{\varepsilon}} \\
& \frac{D k}{D t}=P_{k}-\varepsilon+\frac{\partial}{\partial x_{j}}\left[\left(v+\frac{v_{t}}{\sigma_{k}}\right) \frac{\partial k}{\partial x_{j}}\right]+\pi_{k}^{*} \\
& \frac{D \widetilde{\varepsilon}}{D t}=C_{\varepsilon 1} \frac{\widetilde{\varepsilon}}{k} P_{k}-\frac{\widetilde{\varepsilon}}{k}\left(C_{\varepsilon 2} \widetilde{\varepsilon}+\hat{\varepsilon}\right)+\frac{\partial}{\partial x_{j}}\left[\left(v+\frac{v_{t}}{\sigma_{c}}\right) \frac{\partial \widetilde{\varepsilon}}{\partial x_{j}}\right]+E \\
& P_{k}=-\overline{u_{i} u_{j}} \frac{\partial U_{i}}{\partial x_{j}} \\
& \hat{\varepsilon}=2 v\left(\frac{\partial \sqrt{k}}{\partial x_{j}}\right)^{2}: \frac{\partial \sqrt{k}}{\partial x_{j}} \geq 0, \hat{\varepsilon}=0: \frac{\partial \sqrt{k}}{\partial x_{j}}<0 \\
& \pi_{k}^{*}=-\frac{1}{2} v \frac{\partial}{\partial x_{j}}\left[\frac{k}{\varepsilon}\left(\frac{\hat{\varepsilon}}{\varepsilon}\right)^{2} \frac{\partial \hat{\varepsilon}}{\partial x_{j}}\right] \\
& E=C_{\varepsilon 3} v v_{t} \frac{\partial^{2} U_{i}}{\partial x_{j} \partial x_{k}} \frac{\partial^{2} U_{i}}{\partial x_{j} \partial x_{k}} \\
& f_{\mu}=1.0-\exp \left\{-\left(n_{\eta} / 285\right)-\left(n_{\eta} / 20\right)^{3}\right\} \\
& \sigma_{k}=1.0-0.5 \exp \left[-\left(n_{\eta} / 20\right)^{2}\right] \quad(\mathrm{a} .10), \quad \sigma_{\varepsilon}=\sigma_{k} \\
& n_{\eta}=n / \eta \\
& n \text { は壁面垂直距離を表す. } \\
& C_{\mu}: 0.09, \quad C_{\varepsilon 1}: 1.44, \quad C_{\varepsilon 2}: 1.92, \quad C_{\varepsilon 3}: 0.6
\end{aligned}
$$

表わすパラメータとして用いるもので, $\omega の$ 壁面境界 条件の設定が容易であるなどの特徵がある. 本研究で はこれらの既往モデルの長所, 欠点を客観的に評価す るのが主目的で, 改良案はその結果として述べるにと どめる.これらのモデルはそれぞれの略記とともに 表ー 1 にまとめられている. またモデル式の詳細およ 


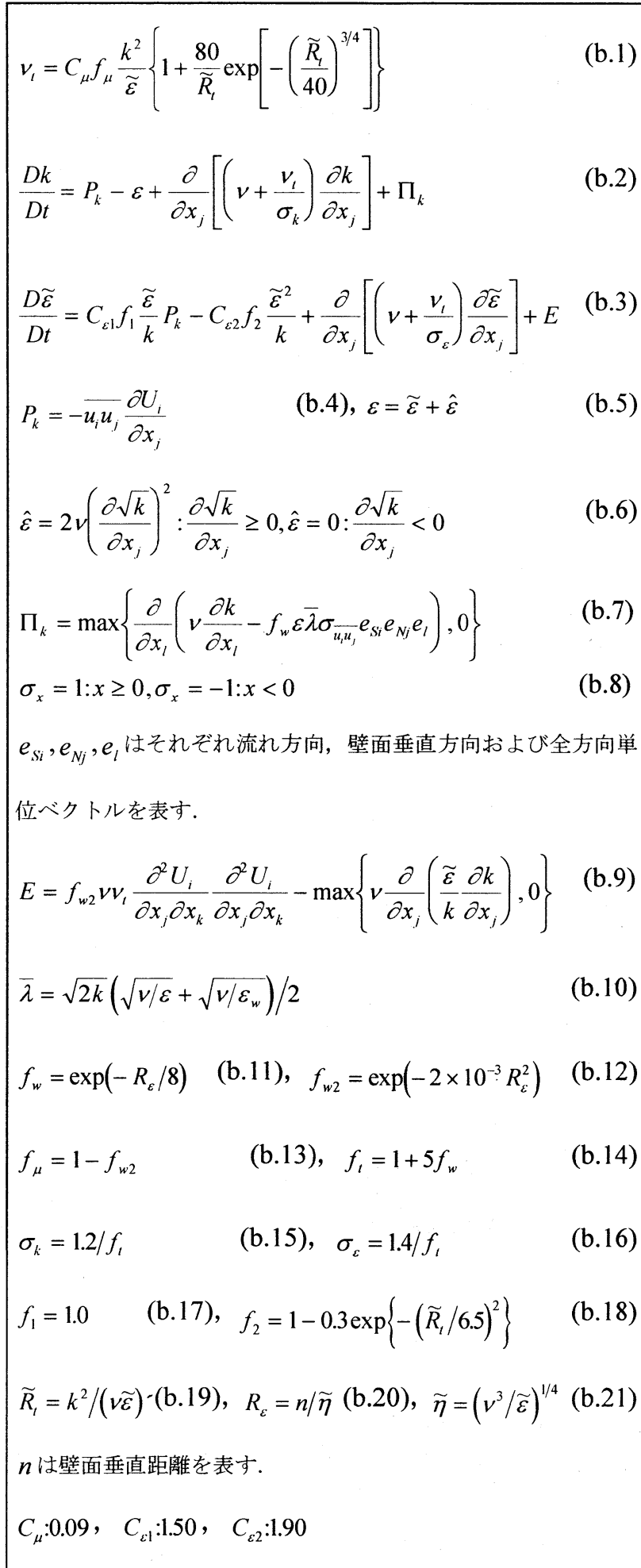

び定数の值は表一 2 から表一 5 にまとめてある.これ らのモデルの基本的性能はそれぞれの文献に説明され ているが，全て壁法則などの相似則を必要とせず，壁 まで適用できる．ただし，比較基準として，壁関数を

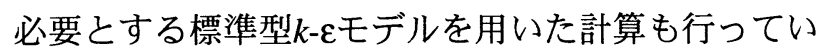

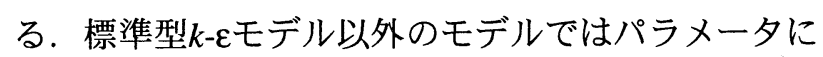

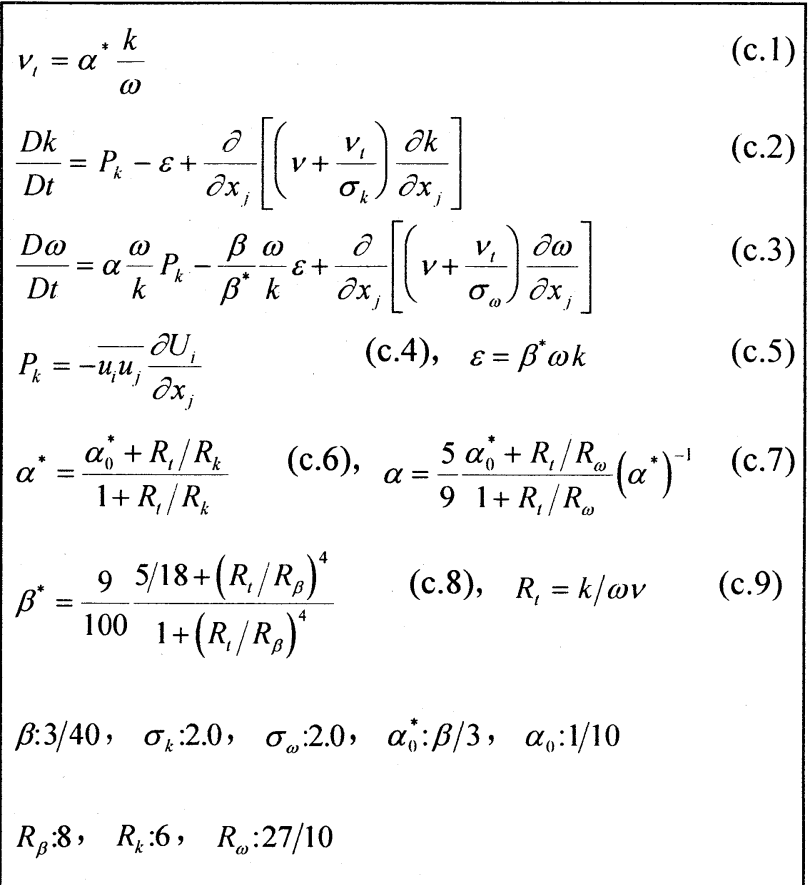

\section{表ー5ＬOPモデルの詳細}

$$
\begin{aligned}
& v_{t}=f_{\mu} \frac{k}{\omega} \\
& \frac{D k}{D t}=P_{k}-\varepsilon+\frac{\partial}{\partial x_{j}}\left[\left(v+\frac{v_{i}}{\sigma_{k}}\right) \frac{\partial k}{\partial x_{j}}\right] \\
& \frac{D \omega}{D t}=C_{\omega 1} f_{\omega} \frac{\omega}{k} P_{k}-\frac{C_{\omega 2}}{C_{k} f_{k}} \frac{\omega}{k} \varepsilon+\frac{\partial}{\partial x_{j}}\left[\left(v+\frac{v_{1}}{\sigma_{\omega}}\right) \frac{\partial \omega}{\partial x_{j}}\right] \\
& +C_{\omega} \frac{v_{t}}{k}\left(\frac{\partial k}{\partial x_{j}} \frac{\partial \omega}{\partial x_{j}}\right) \\
& P_{k}=-\overline{u_{i} u_{j}} \frac{\partial U_{i}}{\partial x_{j}} \quad \text { (d.4), } \quad \varepsilon=C_{k} f_{k} \omega k \\
& R_{t}=k / \omega v(\mathrm{~d} .6), \quad f_{\mu}=0.025+\left\{1-\exp \left[-\left(\frac{R_{t}}{10}\right)^{3 / 4}\right]\right\} \\
& \times\left\{0.975+\frac{0.001}{R_{t}} \exp \left[-\left(\frac{R_{t}}{200}\right)^{2}\right]\right\} \\
& f_{\omega}=1+4.3 \exp \left[-\left(\frac{R_{t}}{1.5}\right)^{1 / 2}\right] \\
& f_{k}=1-0.722 \exp \left[-\left(\frac{R_{t}}{10}\right)^{4}\right] \\
& C_{k}: 0.09, \quad C_{\omega 1}: 0.42, \quad C_{\omega 2}: 0.075, C_{\omega \omega}: 0.75, \quad \sigma_{k}: 0.8, \quad \sigma_{\sigma}: 1.35
\end{aligned}
$$


壁面摩擦速度 $u_{\tau}$ を用いないので, 逆流を伴う流れで $u_{\tau}=0$ となる場合にも数值的問題なく適用できる. また LEKモデルとLENモデルは壁近傍で乱流エネルギーの 圧力拡散を考慮にいれ, 散逸率をの壁面近傍の挙動を

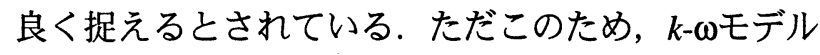
に比べ壁近傍では非常に密な格子が要求される. LOPモデルはLOWモデルの改良モデルで, クロス拡 散の影響を入れており, 逆流計算に適している12).

\section{3. 数値計算法}

上記の運動方程式およびパラメータ $k, \varepsilon, \omega の$ 解法とし て, 仮定した初期值から非定常時間発展計算を行い, 変化のなくなるまで計算を行い結果を求めた. 運動方 程式, 及び乱流パラメータの輸送式の時間進行は Eulerの陽的解法で, 各時間ステップでの圧力は HSMAC法に基づいた反復法で求めた. 速度成分と圧 力は定義点をずらした食い違い格子で, 乱流諸量は全 て格子節点で定義している. なお本計算法の検証は文 献4)に示されているように平坦開水路流, 段落ち流れ で確かめられている.

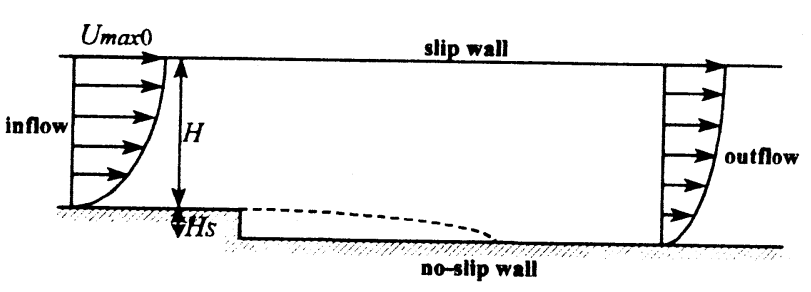

(a) 段落ち流れ

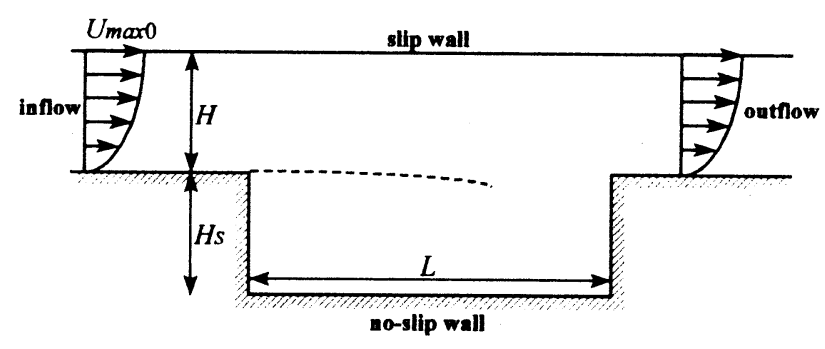

(b) 凹部流れ

\section{図一 1 計算対象流れの概要と記号の定義}

\section{4. 計算ケース}

図一 1 に本研究で対象とする段落ち流れと開水路凹 部流れの概要と記号の定義を示してある. 双方とも

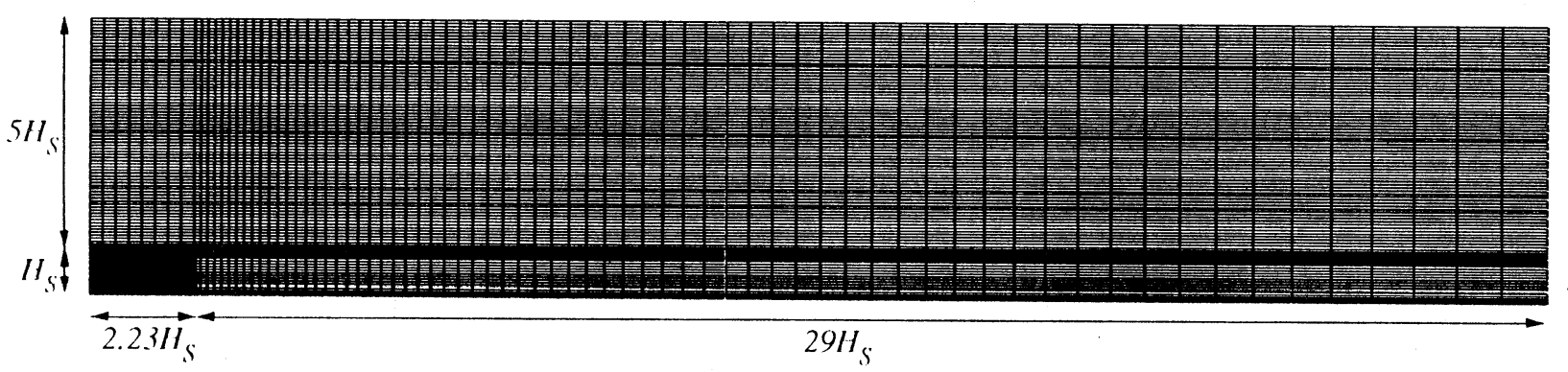

(a) 段落ち流れ

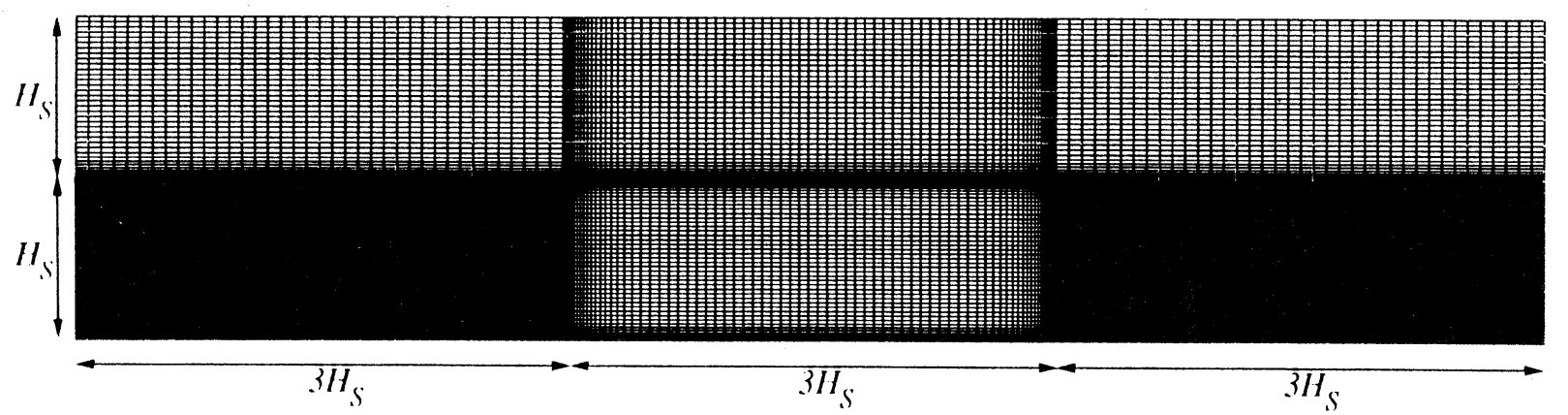

(b) 凹部流れ

\section{図一2 計算領域と格子}




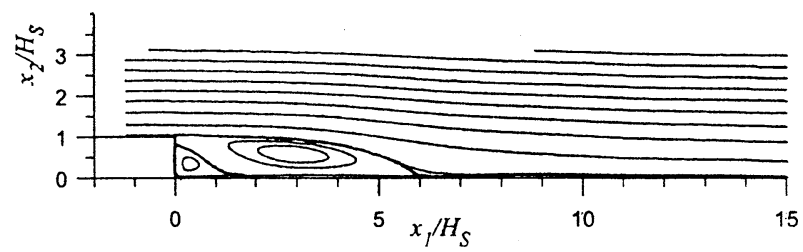

\section{- ー - DNS の剥離流線}

(a) DNS, Le et al. ${ }^{13)}$

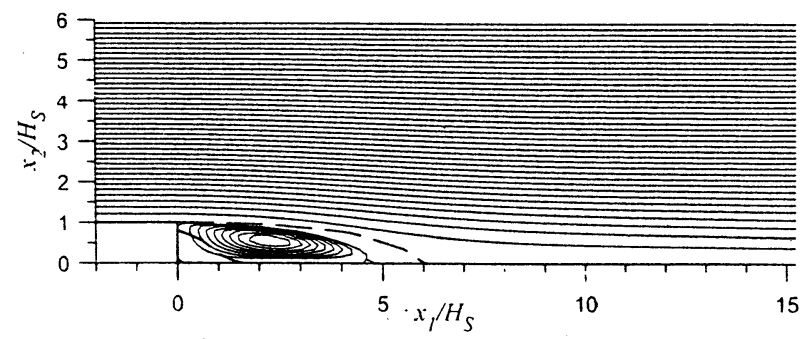

(b) SKEモデル

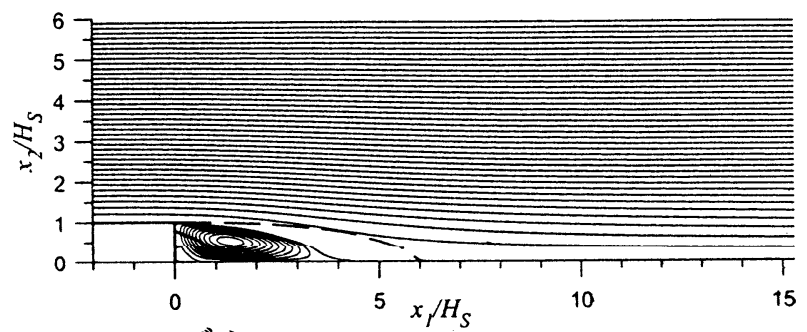

(c) LEKモデル

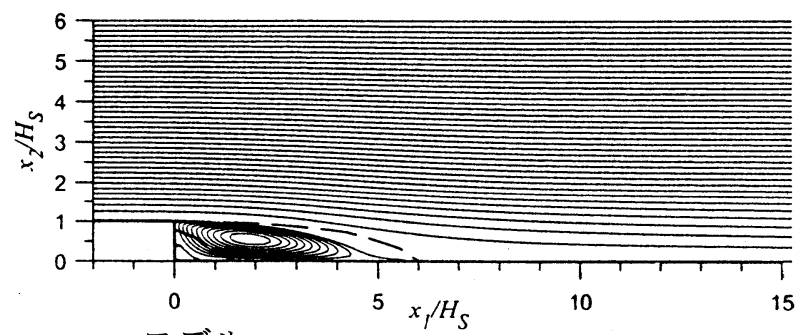

(d) LENモデル

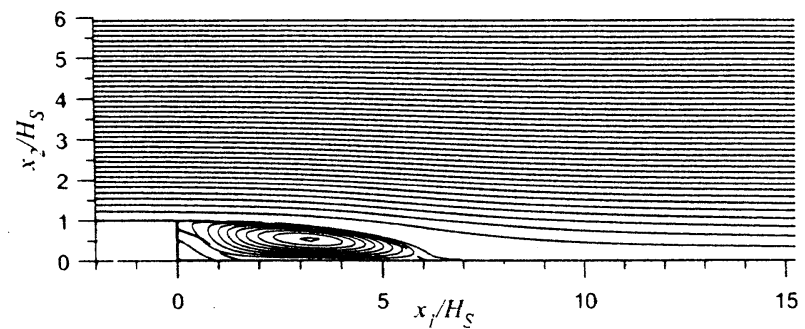

(e) LOWモデル

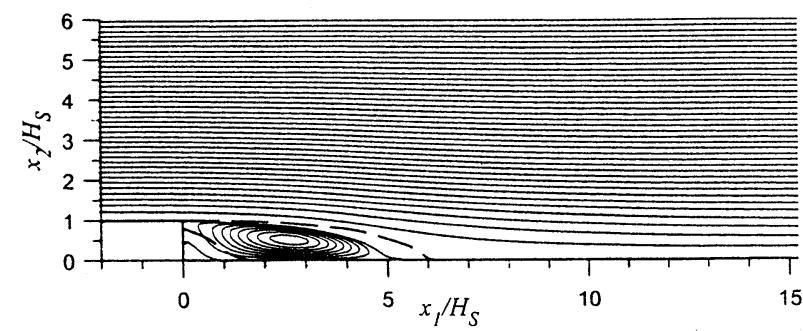

(f) LOPモデル

図一３段落ち流れ計算結果，平均流線図

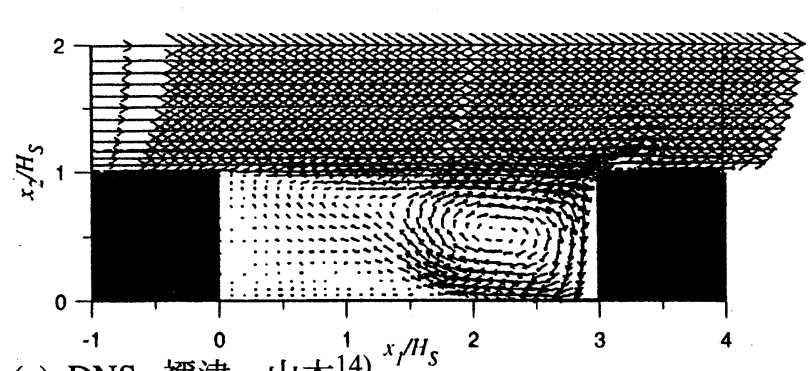

(a) DNS, 襧津 $・$ 山本 ${ }^{14)}{ }^{2} s_{S}$
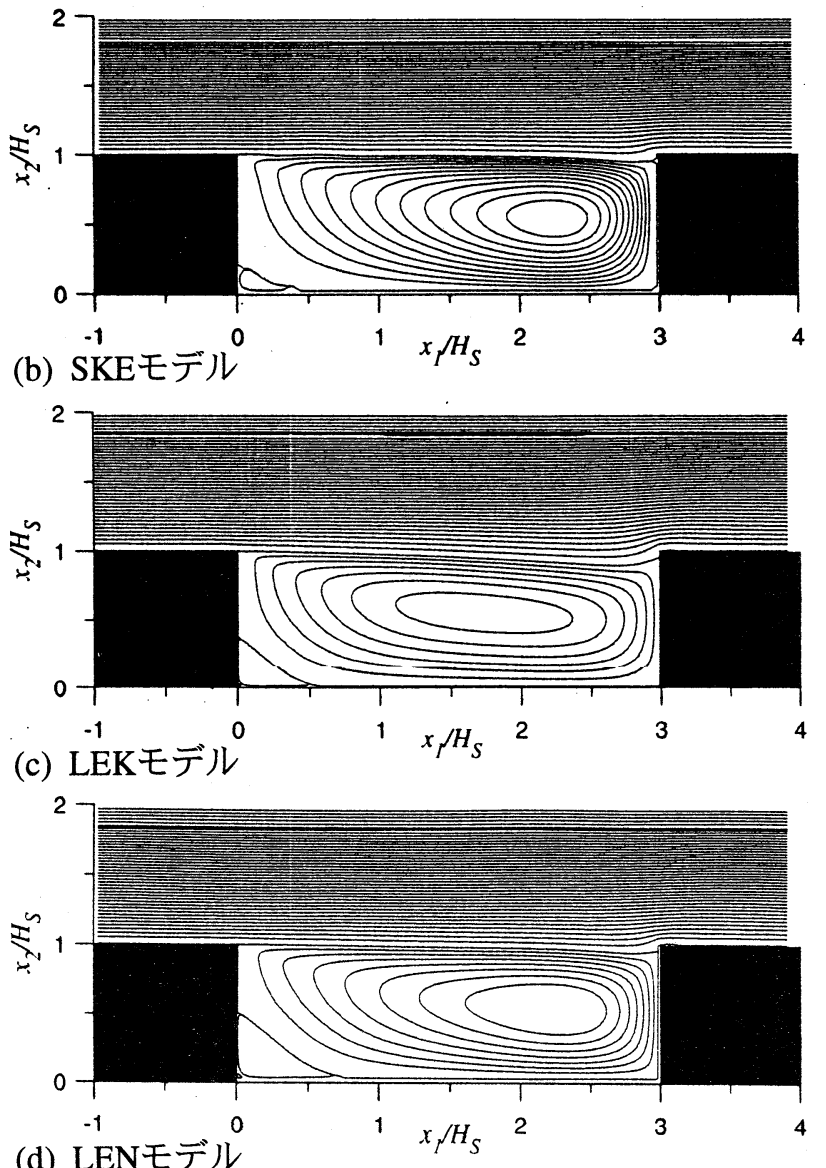

(d) LENモデル
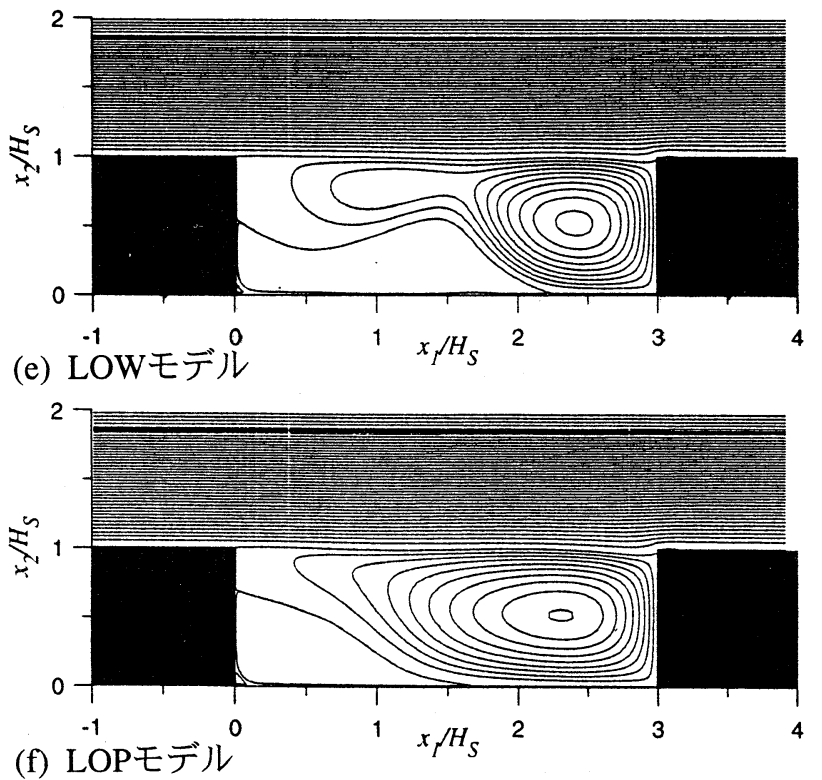

図一4 凹部流れの計算結果, 平均流線図 

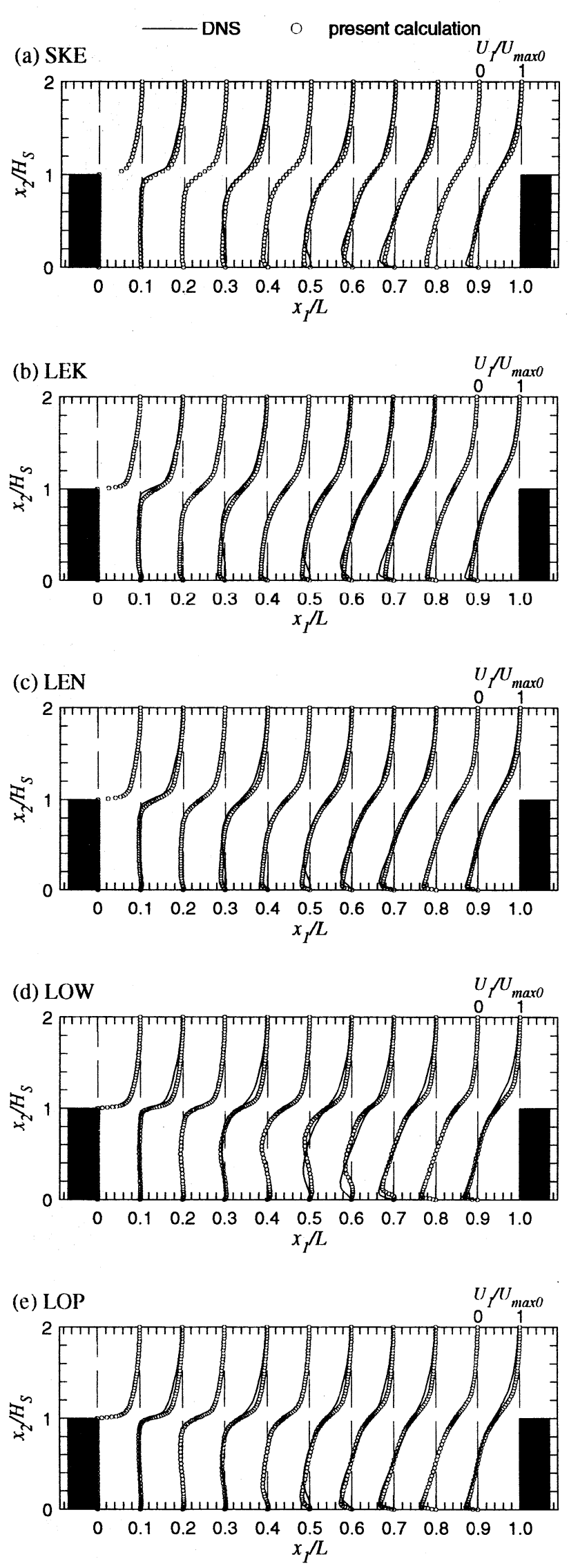

図一 5 段落ち流れ計算結果, 平均速度分布
DNS計算がなされており, 詳細な検証が可能である. 段落ち流れはLe et al. ${ }^{13)}$ により，また凹部流れは禰津 ・山本 ${ }^{14)}$ により計算されているものである. ただどち らのケースも水面は固定すべり面とされているのでフ ルード数は実質ゼロの水面変動効果のないものであ る. また最大流速とステップの高さを基にしたレイノ ルズ数はそれぞれ6000，6300とかなり低い．凹部流れ のDNS計算は流れ方向に周期条件が用いられている が, 両ケースとも上流端でDNS值を流入条件として与 えている. 凹部流れのDNSでは乱れを発達させるため に流れ方向に周期条件を用いているが，計算ではス テップ面からステップ高さ $H_{S}$ の 3 倍の距離の位置で 流入条件を設定し, 下流端は段上がりよりやはり $3 H_{S}$ 下流の面で自由流出条件を設定している. 両方と も実験の状況を再現しており, 比較検証には問題ない と考えられる.

これらの流れの数值計算に用いた計算格子は図一 2 に示されている，共に壁近傍で格子密度が高くなる不 等間隔で, メッシュ数は段落ち流れのケースで $76 \times 96$ ，凹部流れのケースで $151 \times 81$ である．格子間 隔はモデルにより多少異なっている.

\section{5. 計算結果と考察}

まず平均流の計算結果から考察する. 図一 3 に段落 ち流れの計算結果とDNSデータの平均流流線を, 図一 4に凹部流れについての同様の結果を示してある. ど ちらの場合も循環域での流線の数が少なくなりすぎな いよう流線間隔は外側の $1 / 2$ につてある．DNSデー 夕の図での流線間隔とは多少異なるが, 比較に支障は ない. $k$-E型モデルはいずれも循環域の長さがDNSの それより短くなっている. 特に標準 $k$ - $\varepsilon$ モ゙ルでは剥 離流線の形状も異なり, ステップ下隅角部の 2 次剥離 が無いなど定性的にも合っていない。これに対し $k$ 系モデルは剥離流線の形状, 2 次剥離ともDNS と良 く合っており良好な結果が見て取れる.

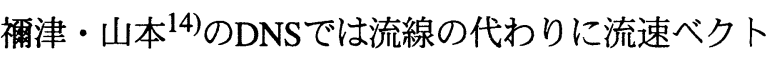
ルが報告されているのでそれを比較基準として示して ある. 段落ち流れの計算結果と比較すると凹部下流端 壁の及ぼす影響がよく分かる. 段落ち流れで循環域が 長く予測されているモデルは凹部循環渦は下流に寄 り, 形状は流れ方向に圧縮されている. 逆に段落ち流 れの循環域を短く予測しているモデルは凹部内循環渦 の形状は流れ方向に長い. 凹部内の循環流が最も圧縮 されているLOWモデルの結果では凹部中心付近でか 


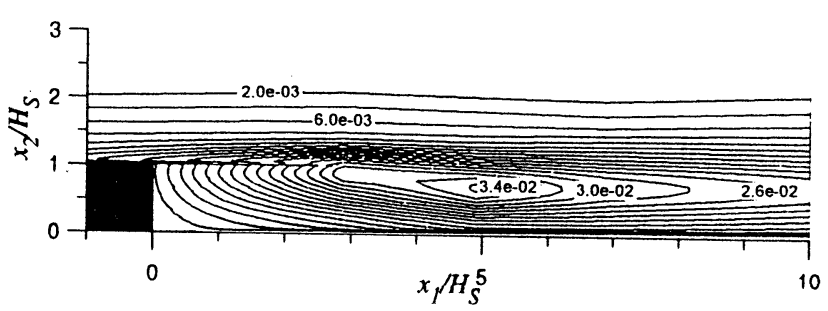

(a) DNS, Le et al. ${ }^{13)}$

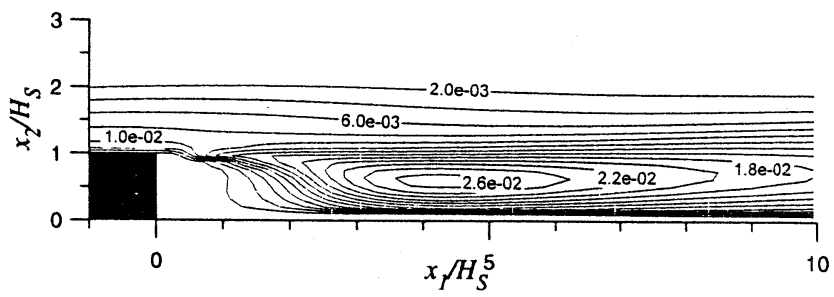

(b) SKEモデル

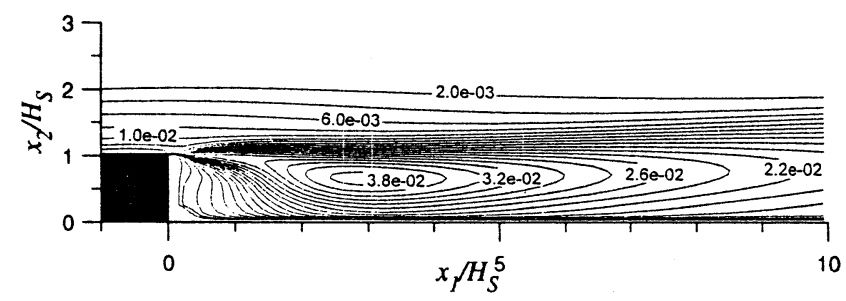

(c) LEKモデル

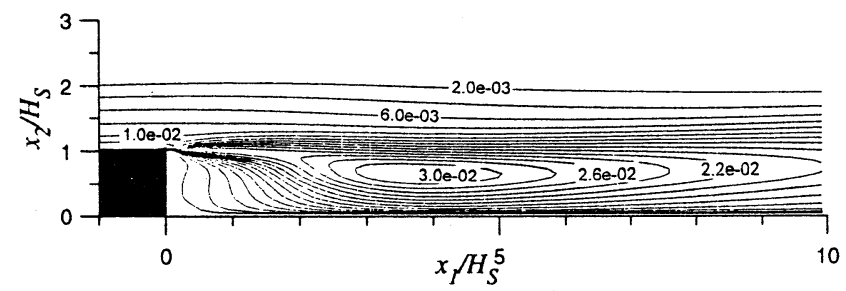

(d) LENモデル

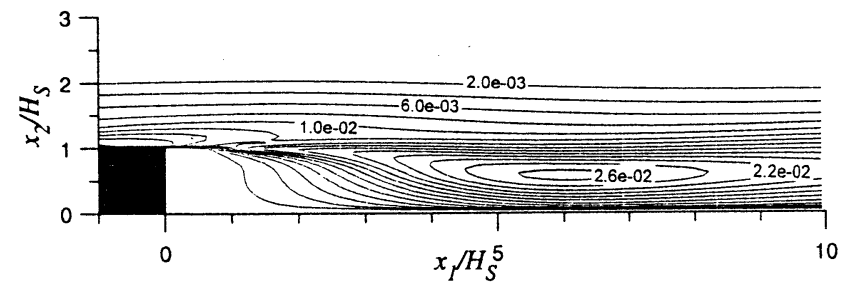

(e) LOWモデル

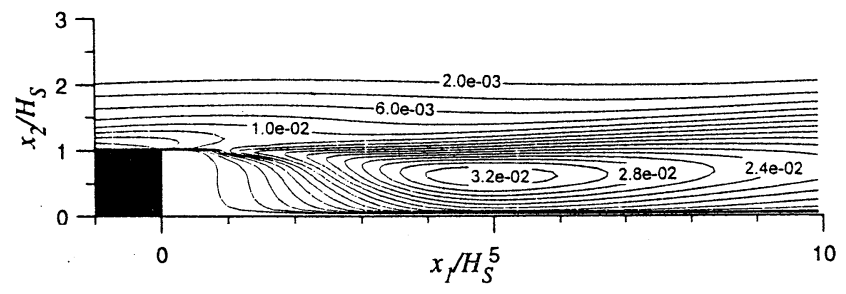

(f) LOPモデル

図一 6 段落ち流れ計算結果, $k / U_{\max 0}{ }^{2}$

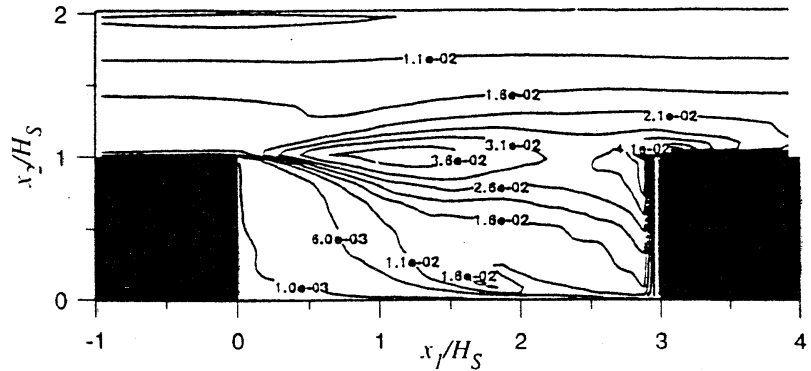

(a) DNS, 襧津 $\cdot$ 山本 $^{14)}$

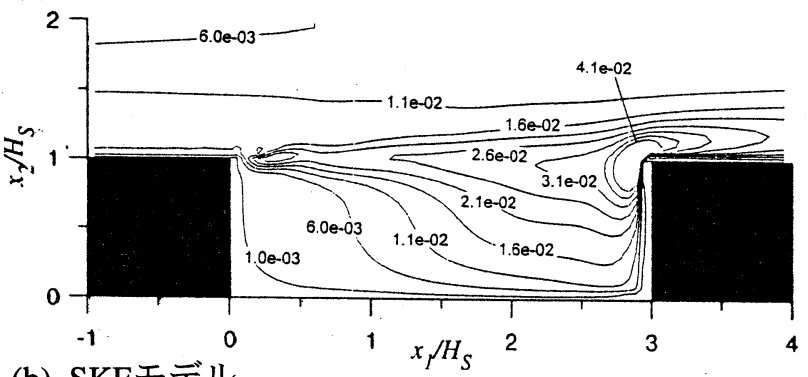

(b) SKEモデル
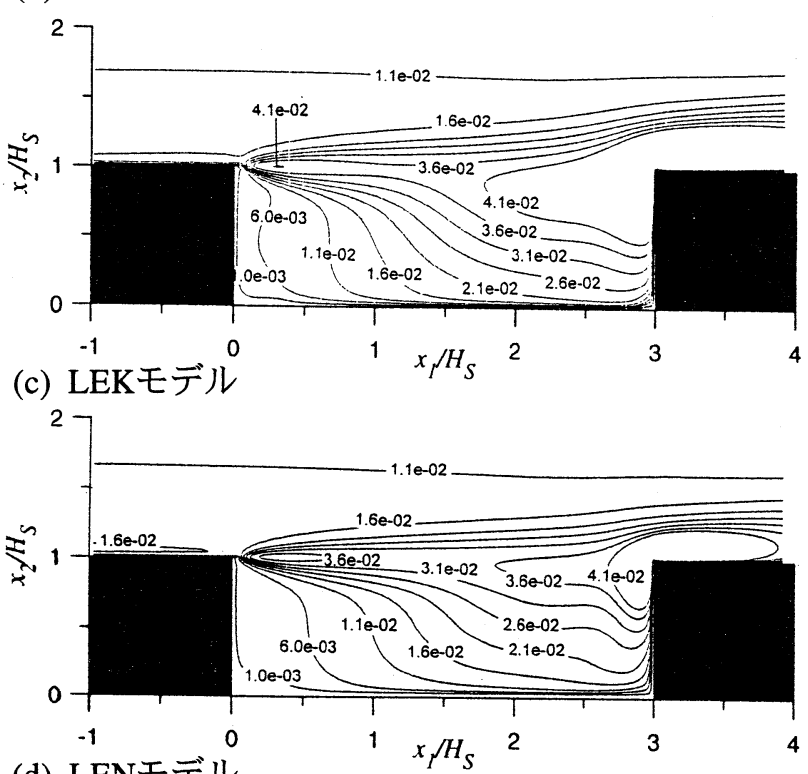

(d) LENモデル

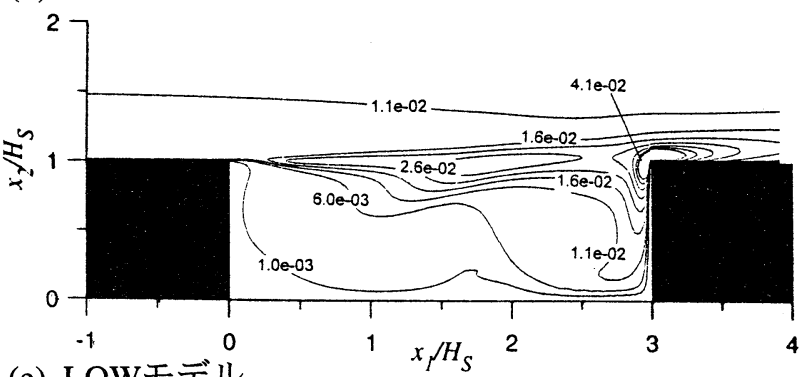

(e) LOWモデル

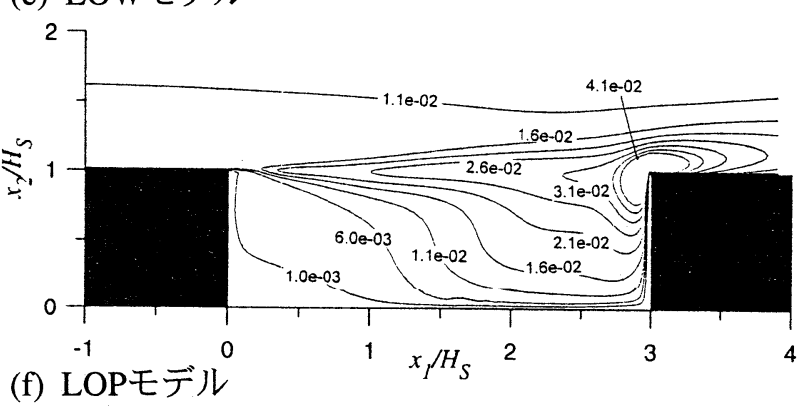

図-7 凹部流れの計算結果, $k / U_{\max 0}{ }^{2}$ 
なり強い上昇流が見られ，第 2 の渦が上流側に形成さ れかけている. LOPモデルの流線の形状は, 凹部底面 中央付近の流線がやや上昇しながら上流側に向かって おり，DNSと最も合っている.

平均流速の予測性を評価するために凹部流のケース の鉛直断面でのそれぞれの主流方向速度分布の計算結 果を螎津・山本 ${ }^{14)}$ DDNSデータとを図一 5 に比較して ある. 速度分布は上流での境界層の厚さとその続きで ある剥離せん断層の広がりの度合に大きく影響してい るようである. LOWモデルでは凹部上流端でのせん 断層の厚さが薄いため, 広がりが過小予測されてい る. 下流端近傍の分布は全てのモデルともDNSと良く 合っている.

次に乱流量の計算結果を検証する. 図一 6,7 は乱 流エネルギー $k$ の結果を等値コンター図として比較し たもので, 図一6は段落ち流れ, 図一7は凹部流れに ついてである. Le et al. ${ }^{13)}$ のNSデータは流れ方向に 5個の断面での乱流エネルギーデータよりコンター図 を作成したのでステップ角付近は不正確であるので注 意を要する. 本計算ケースの凹部アスペクト比では, 上流端角からの剥離せん断層と，それが下流壁に衝突 した後凹部下層を逆流し凹部中央付近で上昇する流れ との相互作用で乱れが大きくなる特徵があることが報 告されている14)。この特徵をいかに良く捉えるかは乱 流モデルの評価に重要である. 段落ち流れではこの相 乗作用がないため, 乱れエネルギー分布と循環域の長 さは良く相関している.すなわちいずれの場合も再付 着点近傍で極大值をとっている. 凹部流れの場合, $k$ 系モデルでは凹部中央付近より上流端角付近に極大 値が見られ， $k$ - $\omega$ 系モデルでは全体的に值が低い. LENモデルの結果が最もDNS值に近い. 下流壁衝突域 近傍での過剩な乱流エネルギーはほぼ全てのモデルに 見られるが, LOWモデルでは最も程度が低い。この 過剰な乱れ生成は, Kato \& Launder ${ }^{15)}$ が角柱まわり の流れの計算で, $k$ の生成項を修正することにより回 避している. 禰津・山本 ${ }^{14)}$ は同様の修正を凹部流れに も適用すべきという指摘があるのでここで, Kato \& Launder ${ }^{15)}$ 修正を導入した計算を行った. 結果は図一 8 に示してある. 図一 4 (b), 図一 7 (b) と比較して分 かるように修正の効果は非常に小さい. 角柱の場合, ポテンシャル流が衝突するので乱れ生成に寄与しない 非回転性歪み速度が大きいが，この凹部流れのよう に, せん断流が衝突する場合非回転成分は小さくKato \& Launder ${ }^{15)}$ 修正の効果は小さいと推察出来る.

図一 9 は凹部流れのせん断応力 $-\overline{u_{1} u_{2}} / U_{\max 0}{ }^{2}$ の計 算結果をDNSと比較したものである. DNSでは $k$ と同

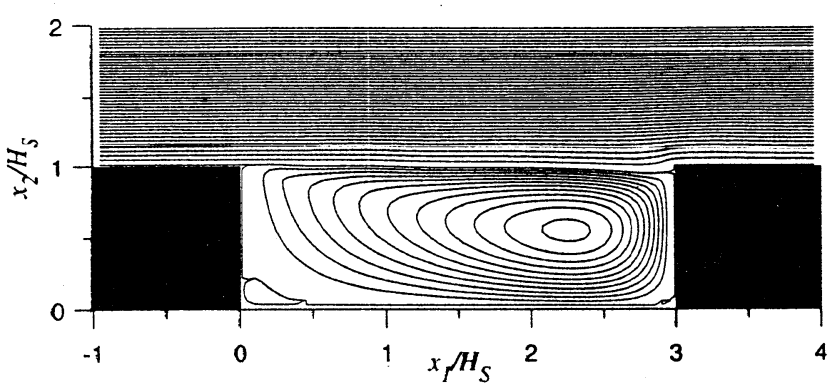

(a) 平均流線

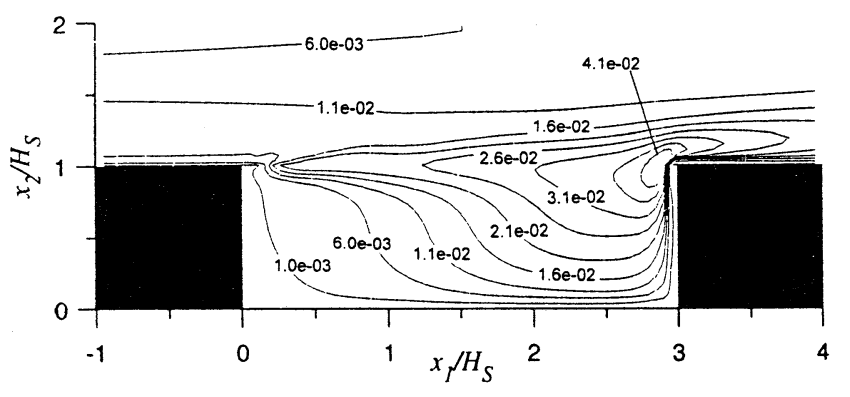

(b) 乱流エネルギー

\section{図-8 Kato-Launder ${ }^{15)}$ の生成項修正の影響,

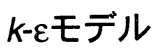

様凹部中央付近で大きな值をとつているが， $k$ 系モデルではこの傾向が全く見られない. それに対 し值がやや低いが, LOWモデルの $k$ コンター形状は DNSに近い.عの壁面漸近性の再現では他のモデルに 劣るLOWモデルが他のベンチマーク流れと同様4)この 流れでも全体的良い予測結果となっている．ただ凹部 流れでの $k$ とせん断応力の過小予測は, 凹部中央付近 で特有の非等方性が表わされていないためと推察され る.

\section{6. 結論}

等方性渦粘性仮定を用いる 2 方程式乱流モデルを用 いて開水路段落ち流れと凹部流れの計算を行いDNS データと比較検討した結果次のような結論を得た. 剥 離や再付着を伴う複雑な乱流の予測計算には等方性渦 粘性モデルは適していないと従来から指摘されている が, 適切な低レイノルズ数モデルは再付着する剥離 流, 衝突する剥離流ともある程度の予測性能はあり, かなり広範囲の実用計算にも用いられる事が分かっ

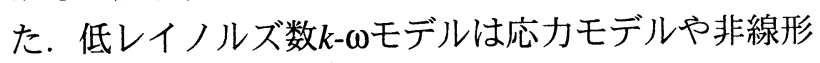
渦粘性モデルなどに比べて効率良い短時間計算で, 平 均流速, 乱流エネルギーの予測では十分精度ある結果 


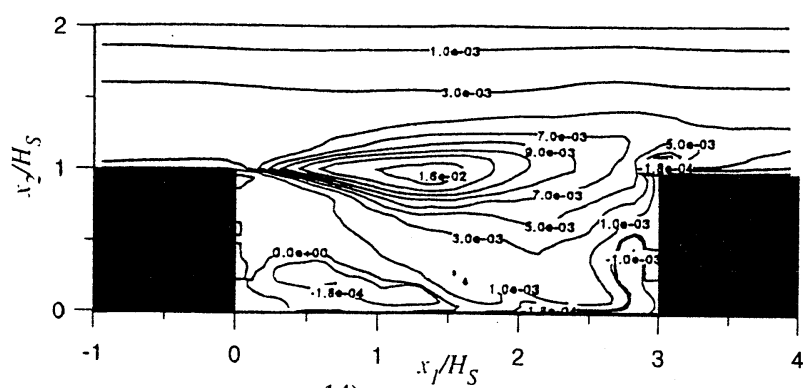

(a) DNS, 襧津 $\cdot$ 山本 ${ }^{14)}$

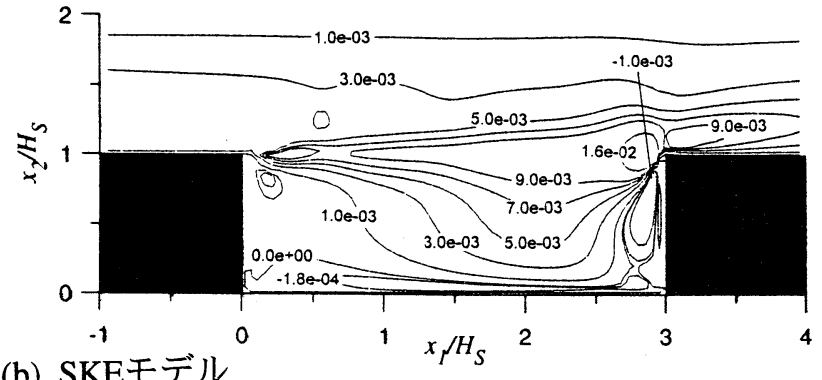

(b) SKEモデル

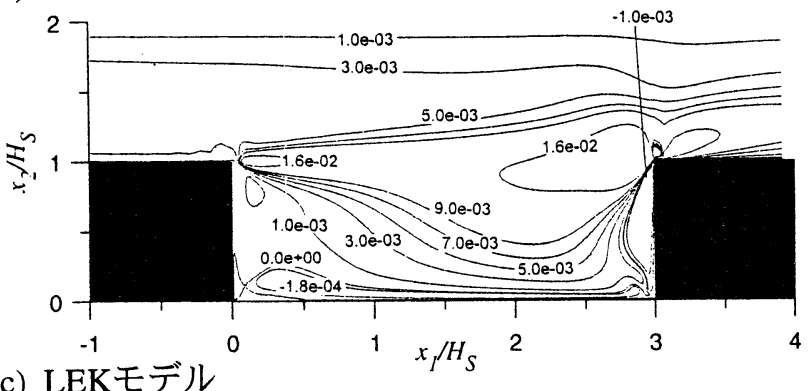

(c) LEKモデル

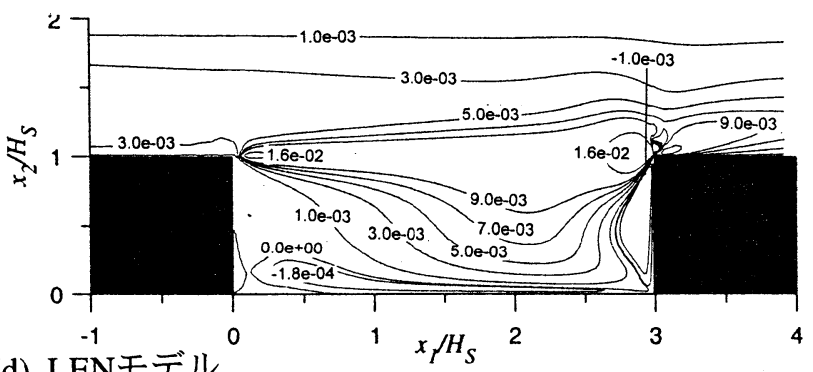

(d) LENモデル

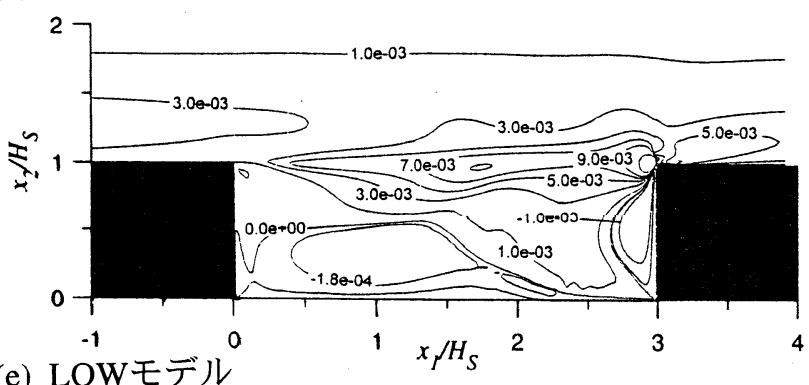

(e) LOWモデル

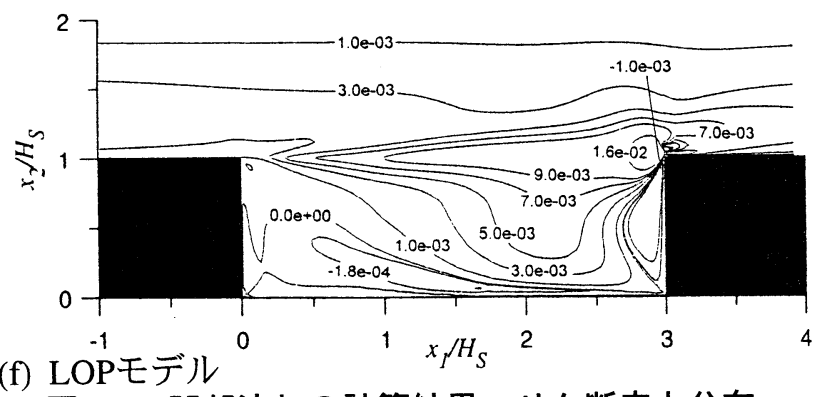

図一9 凹部流れの計算結果, せん断応力分布
が得られる. 今後簡単な方法で異方性の表現が可能に なるような改良がなされれば更に汎用性あるものにな ると考えられる.

\section{参考文献}

1) Launder B.E. and Spalding, D.B.:The Numerical Computation of Turbulent Flows, Computer Methods in Applied Mechanics and Engineering, Vol. 103, pp.456-460, 1974.

2) Rodi, W. and Mansour, N.N.:Low-Reynolds number $k-\varepsilon$ modelling with the aid of direct simulation data, J. Fluid Mech., Vol. 250, pp.509529, 1993.

3) 福知正高, 中山昭彦: 低レイノルズ数乱流モデル を用いた開水路段落ち流れの計算, 水工学論文集 第42巻 pp.471-476, 1998.

4) 中山昭彦, 横嶋哲 : 開水路乱流予測計算における 低レイノルズ数乱流モデルの有用性, 土木学会論 文集投稿中, 1999.

5) Kanda, T., Fujita, I., Miyamoto, H. and Ikegami, J.:Turbulent Behaviors in Open Channel Trench Analyzed by Using PIV and Turbulence Model, Proc. 27th Congress of the IAHR, Theme B, pp.143-148, 1997.

6) 藤田一郎, 神田徹, 門脇正夫, 森田卓光 : 開水路 凹部流れのPIVおよびLESによる乱流解析, 土木 学会論文集, No.539/II-35, pp.79-88, 1996.

7) 宮本仁志, 神田徹, 藤田一郎, 池上迅 : PIVによ る開水路凹部流れの計測および数值解析, 水工学 論文集, 第41巻, pp.1049-1054, 1997.

8）鿅津家久, 山本義暢 : 開水路キャビティー流れの 乱流構造に関する研究, 土木学会論文集, No. 613/II-46-63, 1999.

9) Kawamura, II. and Kawashima, N.:A proposal of $k-\varepsilon$ model with relevance to the near wall turbulence, Proc. Int Symp. on Turbulence, Heat and Mass Transf., pp.P.I.1,1-P.I.1.4, 1994.

10) Nagano, Y. and Shimada, M.:Development of a two-equation heat transfer model based on direct simulation of turbulent flows with different Prandtl numbers, Phys. Fluids, Vol.8, pp.3379,-3402, 1996.

11) Wilcox, D.C.:Turbulence Modeling for CFD, DCW Industries, Inc. La Canada, 1993.

12) Peng, S.-H., Davidson, L. and Holmberg, S.:A Modified Low-Reynolds-Number $k-\omega$ Model for 
Recirculating Flows, J. Fluids Engnrng. Vol. 119, pp.867-875, 1997.

13) Le, H., Moin, P. and Kim, J. :Direct numerical simulation of turbulent flow over a backwardfacing step, J. Fluid Mech., Vol. 330, pp.349-374, 1997.

14）禰津家久, 山本義暢：DNSを用いた開水路キャビ
ティー流れの乱れの生成機構とその輸送過程の解 析, 水工学論文集, 第43巻, pp.377-382, 1999.

15) Kato, M. and Launder, B.E.:The modelling of turbulent flow around stationary and vibrating square cylinders. Proc. 9th Symp. on Turb. Shear Flows, pp.10.4.1-10.4.6, 1993.

（1999年4月23日受付） 